\title{
POSSIBLE RELATION BETWEEN THE SUDDEN SINKING OF RIVER IŠKA AND THE SEQUENCE OF WEAK EARTHQUAKES IN SEPTEMBER-OCTOBER 2010 NEAR IŠKA VAS (CENTRAL SLOVENIA)
}

\author{
MOREBITNA POVEZAVA MED NENADNIM PONIKANJEM \\ REKE IŠKE IN NIZOM ŠIBKIH POTRESOV V SEPTEMBRU IN \\ OKTOBRU 2010 PRI IŠKI VASI (OSREDNJA SLOVENIJA)
}

\author{
Andrej GOSAR ${ }^{1,2} \&$ Mihael BRENČIČ $\check{1}^{1,3}$
}

\begin{abstract}
UDC 550.349:556.53(497.451)

Andrej Gosar \& Mihael Brenčič: Possible relation between the sudden sinking of river Iška and the sequence of weak earthquakes in September-October 2010 near Iška vas (central Slovenia)

During heavy rainfalls between September 17 and 19, 2010 large part of Slovenia has suffered extensive floods that last for nearly two weeks. For the river Iška record discharge of $59.3 \mathrm{~m}^{3} / \mathrm{s}$ was measured on September 19 on the gauging station in Iška vas located at the southern rim of Ljubljansko barje. In the first hour of September 21, 2010 two weak earthquakes $\left(\mathrm{M}_{\mathrm{L}}=0.6\right.$ and $\left.\mathrm{M}_{\mathrm{L}}=0.2\right)$ occurred within one minute near Iška vas. They were felt by some inhabitants who reported also a rumbling noise (brontides). During the flood recession period, the water of river Iška started to sink into the gravely stream bed or rocky left banks and the gauging profile completely dried on September 23, day and a half after the first earthquake. Water reappeared again on September 25. In the period September 21 - October 4 additional seven weak earthquakes occurred in the same area. All earthquakes from this series occurred at or near the surface and deviate in hypocentral depth from the seismicity pattern characteristic for the southern rim of Ljubljansko barje, which was analysed for comparison. The epicentres of the first two earthquakes are in good agreement with the location of the dried river bed. It is therefore probable that both phenomena are related. Analyses of seismograms have shown that it is not likely that the observed events are collapse earthquakes, but they are tectonic events. Although earthquakes were relatively weak, it seems that they could be accompanied by small near-surface tectonic movements, because they occurred at the position of a known fault. These movements are probably connected to the opening of pre-existing fissures in the karstified valley bottom, although the primary reason for sinking of the river is that high waters removed the clogged river bed that enables intensive sinking into the river bottom during the flood.

Keywords: weak seismicity, earthquake, sinking of the river, clogged river bed, karst, hydrograph, river Iška, Slovenia.
\end{abstract}

Izvleček UDK 550.349:556.53(497.451)

Andrej Gosar \& Mihael Brenčič: Morebitna povezava med nenadnim ponikanjem reke Iške in nizom šibkih potresov $v$ septembru in oktobru 2010 pri Iški vasi (osrednja Slovenija)

Po močnem deževju med 17. in 19. septembrom 2010 so velik del Slovenije prizadele obsežne poplave, ki so trajale skoraj dva tedna. Na reki Iški je bil 19. septembra izmerjen rekorden pretok $59,3 \mathrm{~m}^{3} / \mathrm{s}$ in sicer na vodomerni postaji v Iški vasi, ki se nahaja na južnem obrobju Ljubljanskega barja. V prvi uri 21. septembra 2010 sta se pri Iški vasi, znotraj ene minute, zgodila dva šibka potresa $\left(M_{L}=0,6\right.$ in $\left.M_{L}=0,2\right)$. Čutili so ju nekateri prebivalci, ki so poročali tudi o bobnenju (brontid). Med umikanjem poplave je voda Iške pričela ponikati v prodnato dno ali skalnati levi breg. Na vodomerni postaji je voda popolnoma nehala teči 23. septembra, dan in pol po prvem potresu. Voda se je ponovno pojavila 25. septembra. Med 21. septembrom in 4. oktobrom se je na istem območju zgodilo še sedem šibkih potresov. Vsi potresi iz tega niza so nastali na površju ali blizu njega in odstopajo po globini žarišč od vzorca seizmičnosti, ki je značilen za južno obrobje Ljubljanskega barja in smo ga analizirali za primerjavo. Nadžarišči prvih dveh potresov se dobro ujemata s položajem začasno izsušene struge reke, zato je verjetno, da sta oba pojava povezana. Opravljena analiza seizmogramov je pokazala, da ni verjetno, da bi bili opazovani potresi udorne vrste, ampak da gre za tektonske potrese. Čeprav so bili potresi relativno šibki, se zdi da bi bili lahko povezani z majhnimi blizupovršinskimi tektonskimi premiki, saj so nastali na območju znanega preloma. Ti premiki so verjetno povezani $\mathrm{z}$ odpiranjem predobstoječih razpok $\mathrm{v}$ zakraselem dnu doline. Kljub temu pa je primarni vzrok za ponikanje reke ta, da so visoke vode odstranile s sedimenti zapolnjeno rečno dno, kar je med poplavo omogočilo intenzivno ponikanje vode.

Ključne besede: šibka seizmičnost, potres, ponikanje reke, zapolnjeno rečno dno, kras, hidrogram, reka Iška, Slovenija.

\footnotetext{
${ }^{1}$ University of Ljubljana, Faculty of Natural Sciences and Engineering, Aškerčeva 12, SI-1000, Ljubljana, Slovenia

${ }^{2}$ Slovenian Environment Agency, Seismology and Geology Office, Dunajska 47, SI-1000 Ljubljana, Slovenia, andrej.gosar@gov.si

${ }^{3}$ Department of Hydrogeology, Geological Survey of Slovenia, Dimičeva ulica 14, SI-1000, Ljubljana, Slovenia, mihael.brencic@geo.ntf.uni-li.si
}

Received/Prejeto: 21.8.2012 


\section{INTRODUCTION}

During the night of September 21, 2010 two weak earthquakes $\left(\mathrm{M}_{\mathrm{L}}=0.6\right.$ and $\left.\mathrm{M}_{\mathrm{L}}=0.2\right)$ occurred within one minute near Iška vas, $10 \mathrm{~km}$ south of Ljubljana. They were felt by some inhabitants who reported also a rumbling noise (brontides). Nearly simultaneously drying of river Iška started. On September 23 the riverbed at the gauging station Iška vas was completely dry and only on September 25 water appears again. This was particularly strange because only a week before the wider area (Ljubljansko barje) faced with one of the strongest floods in the last decades and the level of river Iška was very high. Two initial earthquakes were followed in the next two weeks by seven weak and shallow events with epicentres distributed within couple of kilometres. Coincidence of weak earthquakes and the sudden sinking of river Iška rose a question on the origin of seismic events as well as on the primary reason for sinking of the river. Two possibilities of tectonic and collapse type earthquakes were considered.

Earthquakes are generally classified by their mode of generation into three classes. By far the most common are tectonic earthquakes. They are produced when rocks break suddenly in response to the stress accumulated due to tectonic forces and movements. Volcanic earthquakes are ones that occur in conjunction with volcanic activity. The actual mechanism of seismic waves genera- tion is probably the same as that of tectonic earthquakes. Collapse earthquakes are small earthquakes occurring in regions of underground karst caverns and mines. The immediate cause of ground shaking is the collapse of the roof of the cavern or mine. An often observed variation of this phenomenon is the mine burst or rock burst (Fairhurst 1990). Collapse earthquakes are sometimes produced also by massive rockfalls or landslides. They are not necessarily triggered by a nearby tectonic earthquake, as often happens (Bolt 1993; Ribarič 1984). Although collapses of the roof of the karst caverns are quite common and frequently reported from different karst areas in the world, there are very few reports on actual collapse earthquakes recorded by seismological stations. The main reason is perhaps in the fact that the cave roof collapse produce normally relatively weak earthquake which can be recorded only on seismological stations which are located relatively close.

In this study a detailed analysis of the observed seismicity in Iška vas area was performed to reveal the origin of seismic events. In addition hydrological conditions during the same period were analysed to get insight into the causes for sinking of the river Iška, which followed its record discharge due to floods, and which started nearly simultaneously with two initial earthquakes. Therefore, it can be expected that both phenomena are related.

\section{GEOLOGICAL SETTING}

Iška vas is located at the southern rim of the Ljubljansko barje (Fig. 1), along the river Iška which flows in the north direction from the Krim-Mokrec mountain range built of Mesozoic carbonates into the flat surface of the Ljubljansko barje (Figs. 1 and 2). South of hamlet Iška the river flows through the narrow canyon (Iški vintgar), which is several kilometres long. Ljubljansko barje is a young sedimentary basin situated in the central Slovenia south of Ljubljana (Fig. 2). It is $23 \mathrm{~km}$ long and up to 12 $\mathrm{km}$ wide and occupies an area of $120 \mathrm{~km}^{2}$. The surface is almost flat, with an average elevation of $290 \mathrm{~m}$. Several hills above this flat surface represent outcroppings of the bedrock (Fig. 2). The basin is filled with lacustrine and fluvial Quaternary sediments. The bedrock is built in the northern part of Carboniferous and Permian sandstones, conglomerates and shale, and in the central and southern part of Triassic dolomite and Jurassic limestone (Mencej 1989). The latter are extensively karstified with rugged surface and several caves and potholes.
The tectonic subsidence of the Ljubljansko barje ba$\sin$ in the form of tectonic graben started at the transition between Pliocene and Pleistocene. It was most intensive in the middle and upper Pleistocene, but it continues to recent times. Subsidence is related mainly to several faults striking in the NW-SE (Dinaric) direction, while the faults striking in the NE-SW and E-W direction are less important. These faults cut the bedrock into several blocks. Differential movements of blocks have resulted in rugged bedrock topography. The depth to the bedrock ranges from $0 \mathrm{~m}$ to $200 \mathrm{~m}$ and is greater in the eastern part of the basin (Mencej; 1989, Gosar \& Lenart 2010). For wider Iška vas area a series of faults striking in the NW-SE direction is characteristic (Fig. 2). In-between some faults are striking in NE-SW direction. The most important NW-SE striking faults are Dobro polje fault, which represents the eastern border of the Ljubljansko barje and Želimlje fault which is running $4 \mathrm{~km}$ east of the Iška vas. On the other hand Mišji dol fault is run- 


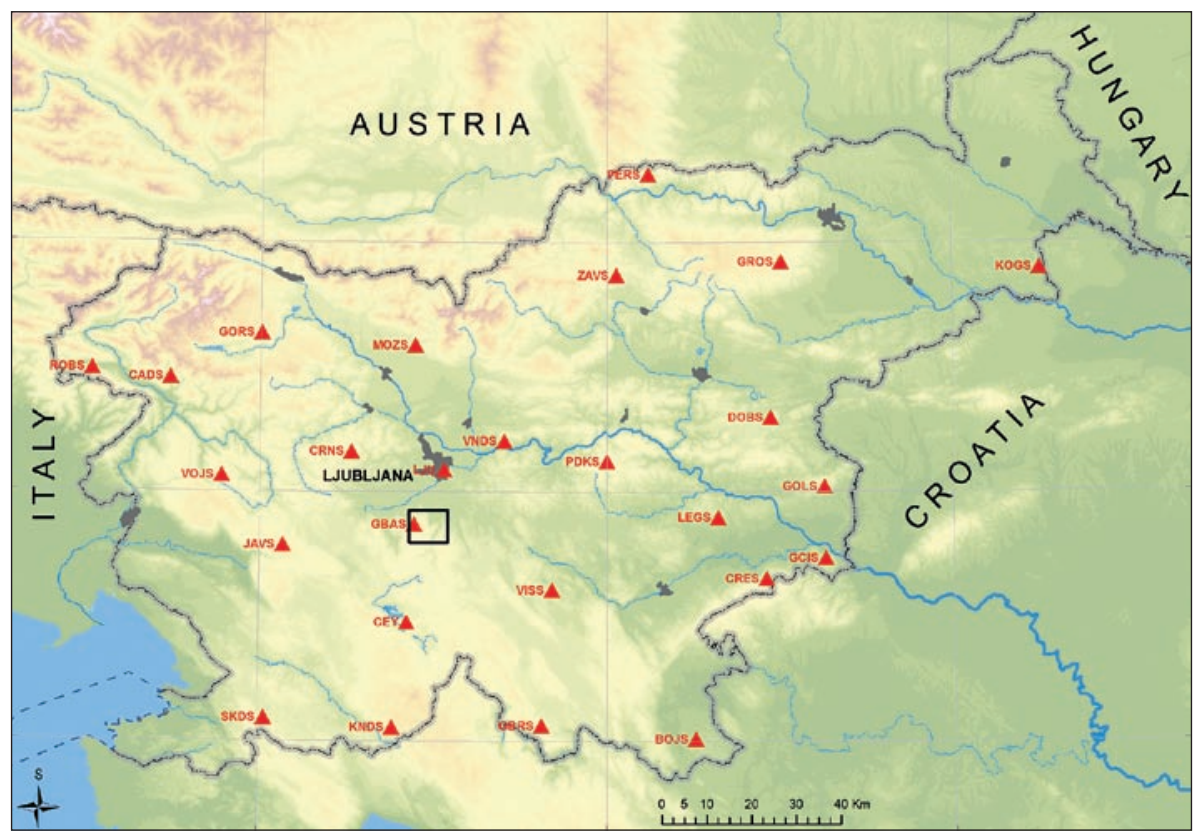

Fig. 1: Map of Slovenia with locations of stations of the Slovenian seismological network. Rectangle indicates the study area.

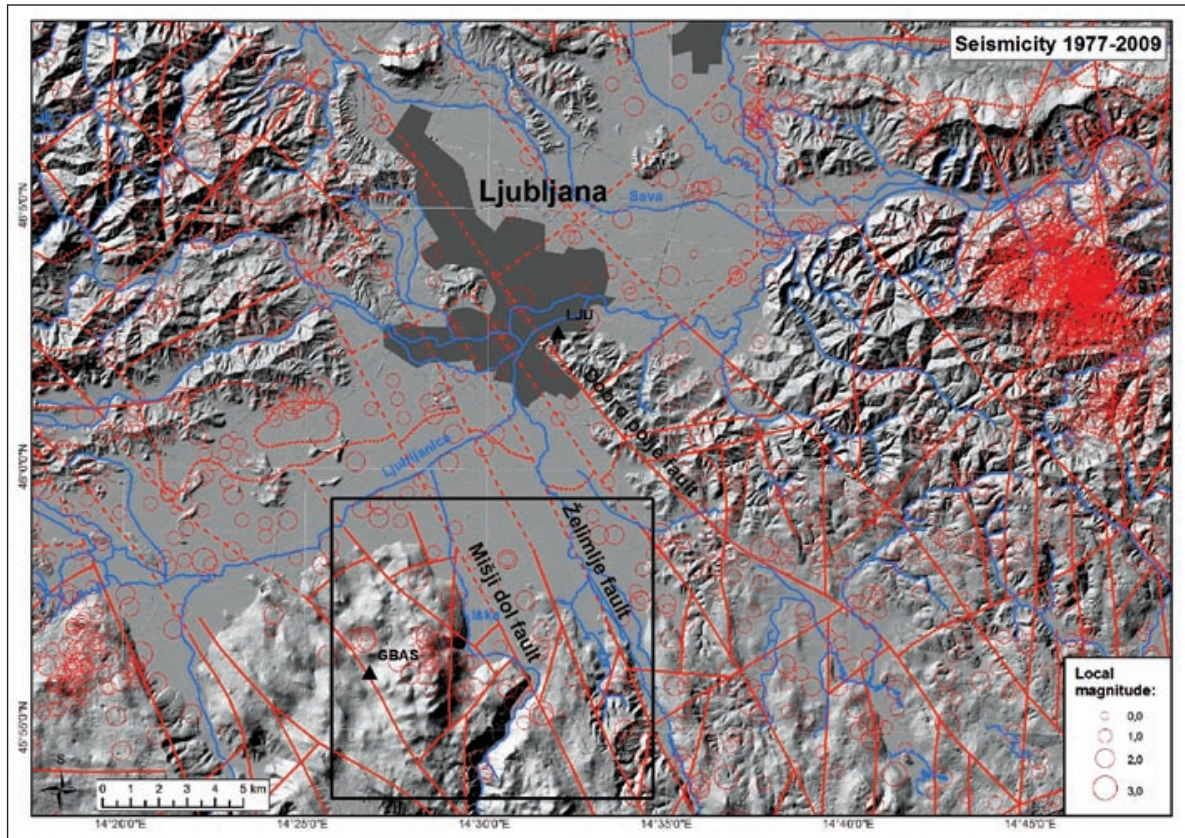

Fig. 2: Seismicity in the wider Ljubljana area in period 1977-2009 (after ARSO 2012) with generalized tectonic elements. Rectangle indicates the study area shown in Fig. 3 ning directly across the Iška vas (Fig. 2). In-between these three faults the deepest part of the Ljubljansko barje basin was developed. Most of the faults, which cut the Ljubljansko barje basin are considered as active faults, although no direct geological or seismological proofs of their activity are available so far. The position of faults is also well established only in the hills, which surrounds the basin. In the bedrock of the basin they were determined mainly by geophysical investigations and sparse drilling (Mencej 1989).

Wider Ljubljana area is characterized by moderate seismicity (Fig. 2). In the whole Ljubljansko barje basin and at its margins the distribution of epicentres is scattered. Therefore, the seismicity can not be directly related to individual faults. More pronounced earthquake activity in the last 25 years is characteristic for the area east of Ljubljana near Litija (Fig. 2). Also the last damaging earthquake $(\mathrm{M}=4.9$, maximum intensity VII MSK) occurred in 1963 in this epicentral region. The most damaging earthquake in the history of the city occurred in 1895 when Ljubljana was hit by an $M=6.1$ earthquake, which caused extensive damage of VIII-IX MCS maximum intensity.

\section{SINKING OF THE RIVER IŠKA}

During heavy rainfalls between September 17 and 19, 2010 large part of Slovenia has suffered extensive floods that last for nearly two weeks. In Ljubljansko barje the flood covered surface of $76.8 \mathrm{~km}^{2}$ with the water volume estimated on $34 \times 10^{6} \mathrm{~m}^{3}$. The return period of the flood appearance was estimated on 100 years (Globevnik \& 


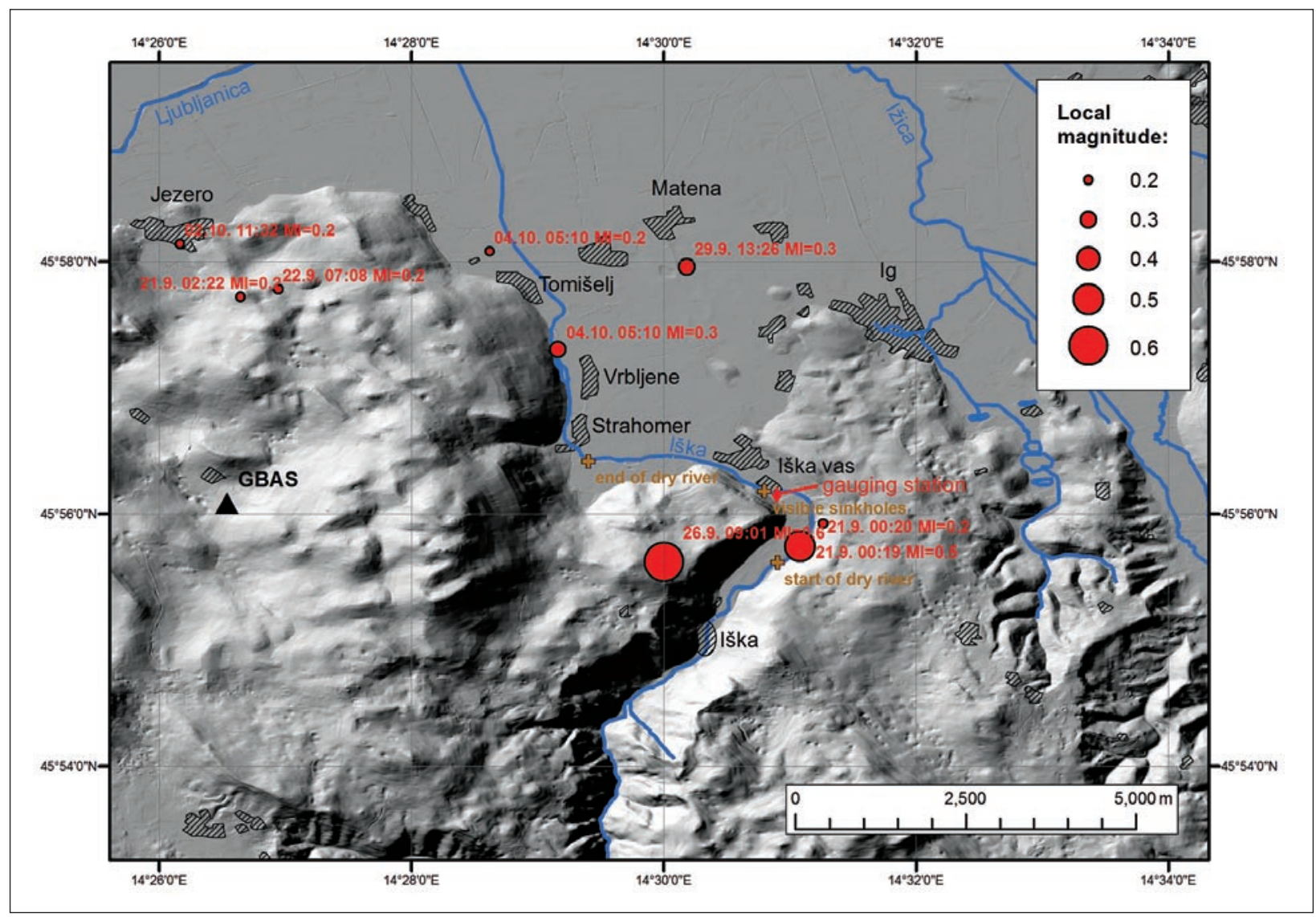

Fig. 3: Seismicity in the Iška vas area between September 21 and October 4, 2010. Indicated are areas where river Iška disappeared underground and where it appeared again on the surface as well as the location of visible sinkholes in the riverbed.

Vidmar 2010). During high waters the total amount of water flowing from the recharge area to Ljubljansko barje was more than $400 \mathrm{~m}^{3} / \mathrm{s}$, and one of the largest streams contributing to this amount was river Iška. South of hamlet Iška, river comes out of the canyon and

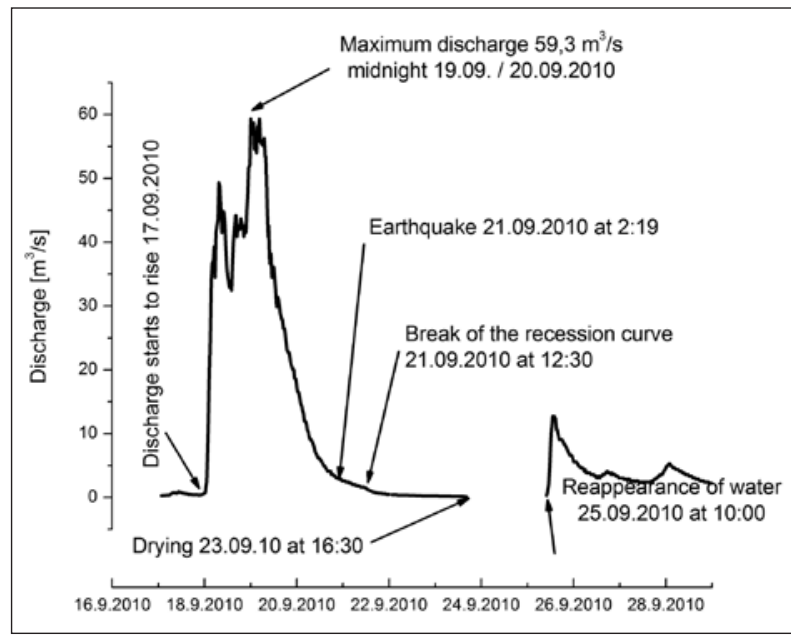

Fig. 4: Hydrograph of river Iška between September 16 and September 29, 2010 (local time $=U T C+2 \mathrm{~h})$. flows from the bedrock channel to the alluvial sediments consisting predominantly of coarse gravel with lenses of sand (Fig. 3). The thickness of the sediments bellow Iška vas is not exactly known. Based on the extrapolation of the bedrock topography from Tomišelj - Brest - Vrbljene area (Fig. 3), the thickness below the centre of Iška vas is estimated to be not less than $20 \mathrm{~m}$ (Janža et al. 2011), but at the southern rim of the village the bedrock outcrops in the river bed. In the past, loses of water into river bed between hamlets Iška and Iška vas were observed based on occasional discharge measurements. Due to the karstified Mesozoic bedrock of the valley and presence of many faults, it is still not know what the amount of loses is and where the water flows. During September 2010 flood recession water started to sink more intensively and for two days the river bed completely dried; phenomenon that in this part of the river was not observed for a long time.

Automatic gauging station on the river Iška operated by the Slovenian Environment Agency (ARSO) is situated on the bridge in Iška vas (Fig. 3). In downstream direction, at the distance of $30 \mathrm{~m}$ from the station, a sill is positioned, which collapsed during the 
September 2010 flood. Discharge data of the gauging station used in our study were reported online (ARSO 2010). Total recharge area at the Iška vas gauging station is $69.7 \mathrm{~km}^{2}$ (ARSO 2008) and the average discharge for the period from 2001 to 2009 is $1.35 \mathrm{~m}^{3} / \mathrm{s}$ (ARSO 2011) At the present position gauging station started to operate in 2001. Before it was positioned upstream at various places inside the hamlet Iška. Older discharge data are therefore not directly comparable with recent measurements.

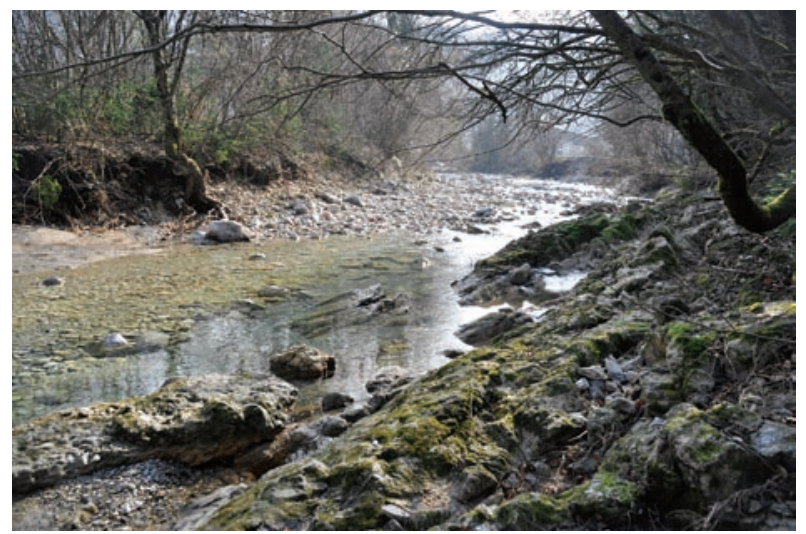

Fig. 5: Outcropping of Mesozoic limestone in the river bed.

During September 2010 heavy rain discharge of river Iška started to rise on September 17 (Fig. 4). On consecutive hours river Iška discharge reached three high peeks. The first peak with $49.3 \mathrm{~m}^{3} / \mathrm{s}$ appeared on September 18 at 7:30 local time. All the hydrological data is provided in local time (Central European time), while seismological data are provided in UTC (Universal Time Coordinated); the difference is 2 hours (local time $=\mathrm{UTC}+2 \mathrm{~h})$. The two following peaks that represent record values for this gauging station have discharge of $59.3 \mathrm{~m}^{3} / \mathrm{s}$. The second one appeared exactly at midnight of September 18 and 19 and the third one on September 19 at 4:30. Hydrograph between the first and the third peak is very irregular and probably does not represent real hydrological conditions at peak discharges. It is believed that real discharges at the maximum flood were much higher and that the shape of the hydrograph in this period is a consequence of the sill collapse downstream and a consequent appearance of a hydraulic jump. Soon after the highest level was reached, water started to fall rapidly. On September 23 at 16:30 gauging profile was already completely dry. Water reappeared at the gauging station again on September 25 at 10:00.

Drying of the river Iška bed in its middle part is a very rare event. The last recorded one happened before the World War II, more than 70 years ago. Sep- tember 2010 drying of the river bed was the consequence of several events and natural conditions of the river bed. In normal situation the river bed on the Iška vas section is clogged with fine sediments composed of clay and silt. The alluvial fan of the river is represented by high permeable gravel pack and positioned on the karstified limestone where karstified fissures are present. The limestone also outcrops on the river banks (Fig. 5). During the flood event of September 2010 high waters removed up to $1.5 \mathrm{~m}$ of the clogged

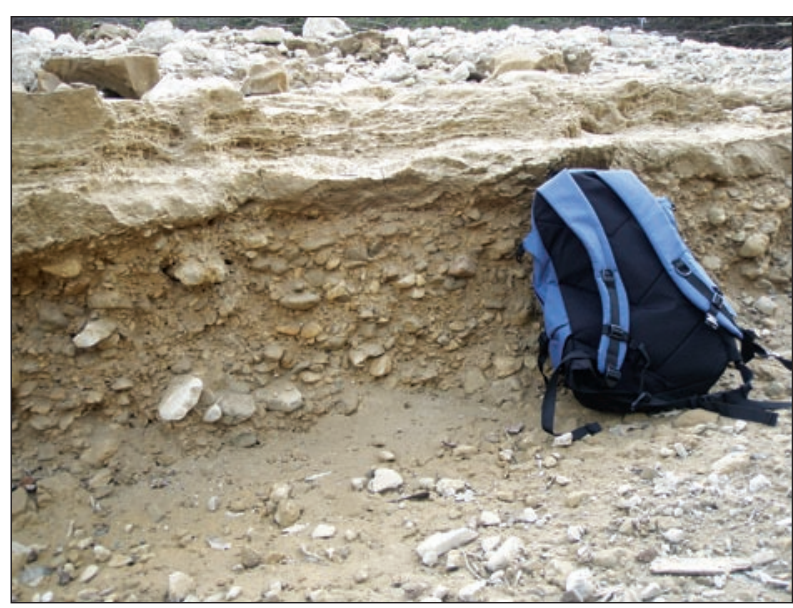

Fig. 6: Outcrop of the clogged river bed after the flood event.

river bed (Fig. 6). Several springs in the limestone on the left bank were also observed above the river's water table. After the end of the rainfall, springs on the banks dried and river started to sink in the cleared river bottom. Sinking appeared along the whole river bed as well as in cleared fissures in Jurassic limestone representing small sink holes. Mapping of the river bed performed after the drying event showed that before the flood, river water hang above the groundwater, due to low permeability of the river bed. With the removal of the low permeable bed and lowering of high groundwater head from the karstified limestone aquifer in the valley bottom, river water started to sink (Brenčič 2011).

Before the final stage of flood recession, in the first hour of September 21 (UTC) two weak earthquakes $\left(M_{L}=0.6\right.$ and $\left.M_{L}=0.2\right)$ occurred within one minute near Iška vas. There is no indication that at the time of the earthquakes any change in the recession limb of the hydrograph occurred (Fig. 3). Break of the recession line can be observed later on the same day (September 21) at 12:30 local time. Two initial earthquakes were followed in the next two weeks by seven weak and shallow events with epicentres distributed within couple of kilometres. 


\section{SEISMIC MONITORING AND LOCATION OF EVENTS}

Earthquakes in Iška vas area were monitored by the Slovenian national seismological network which is operated by Slovenian Environment Agency (Vidrih et al 2006) and consists of 26 broad-band seismological stations (Fig. 1). In the period of 15 days between September 21 and October 4, 2010 nine shallow earthquakes were recorded in this area (Tab. 1).
Two hours later, at 02:22 UTC, another $M_{L}=0.2$ earthquake occurred, but its epicentre was approximately 5 $\mathrm{km}$ to the NW from the previous ones. Next day local people realized that the river started to sink. Also the epicentre of September 22 event $\left(M_{L}=0.2\right)$ was close to the last event on September 21. The strongest earthquake in the series $\left(M_{L}=0.6\right)$ occurred in September 26

Tab. 1: Data for earthquakes which occured in vicinity of Iška vas between September 21 and October 4, 2010 (UTC - Universal Time Coordinated).

\begin{tabular}{c|c|c|c|c|c|c|c|c|c|c}
\hline Year & Date & $\begin{array}{c}\mathrm{HH:MM} \\
(\mathrm{UTC})\end{array}$ & Sec & $\begin{array}{c}\text { Latitude } \\
\left({ }^{\circ} \mathbf{N}\right)\end{array}$ & $\begin{array}{c}\text { Longitude } \\
\left({ }^{\circ} \mathrm{E}\right)\end{array}$ & $\begin{array}{c}\text { Depth } \\
(\mathbf{k m})\end{array}$ & $\begin{array}{c}\text { No.of } \\
\text { stations }\end{array}$ & $\begin{array}{c}\text { RMS } \\
\text { misfit }\end{array}$ & $\begin{array}{c}\text { Gap in } \\
\text { azimuth }\end{array}$ & $\begin{array}{c}\text { Local } \\
\text { magnitude }\end{array}$ \\
\hline 2010 & 0921 & $00: 19$ & 42.7 & 45.929 & 14.518 & 0.1 & 14 & 0.4 & 74 & 0.5 \\
\hline 2010 & 0921 & $00: 20$ & 25.6 & 45.932 & 14.521 & 0.1 & 11 & 0.4 & 74 & 0.2 \\
\hline 2010 & 0921 & $02: 22$ & 5.4 & 45.962 & 14.444 & 0.1 & 8 & 0.3 & 83 & 0.2 \\
\hline 2010 & 0922 & $07: 08$ & 33.1 & 45.963 & 14.449 & 0.1 & 7 & 0.2 & 82 & 0.2 \\
\hline 2010 & 0926 & $09: 01$ & 12.3 & 45.927 & 14.500 & 0.1 & 13 & 0.3 & 79 & 0.6 \\
\hline 2010 & 0929 & $13: 26$ & 2.0 & 45.966 & 14.503 & 0.0 & 9 & 0.4 & 69 & 0.3 \\
\hline 2010 & 1002 & $11: 32$ & 49.8 & 45.969 & 14.436 & 0.1 & 8 & 0.3 & 88 & 0.2 \\
\hline 2010 & 1004 & $05: 10$ & 44.6 & 45.968 & 14.477 & 0.0 & 7 & 0.4 & 78 & 0.2 \\
\hline 2010 & 1004 & $05: 10$ & 51.9 & 45.955 & 14.486 & 0.0 & 6 & 0.3 & 146 & 0.3 \\
\hline
\end{tabular}

In the first hour of September 21, $2010(00: 19$ UTC) two weak consecutive earthquakes $\left(M_{L}=0.6\right.$ and $\left.M_{L}=0.2\right)$ occurred 43 seconds apart, with epicentres in Iška vas (Figs. 3 and 7). They were felt by some inhabitants who reported also a rumbling noise (brontides).
(Fig. 8) and is located again close to Iška vas. The last two earthquakes on October 4 th $\left(\mathrm{M}_{\mathrm{L}}=0.2\right.$ and $\left.\mathrm{M}_{\mathrm{L}}=0.3\right)$ occurred only 7 seconds apart (Fig. 9). Their epicentres were close to Tomišelj, which is located downstream from Iška vas (Fig. 3).

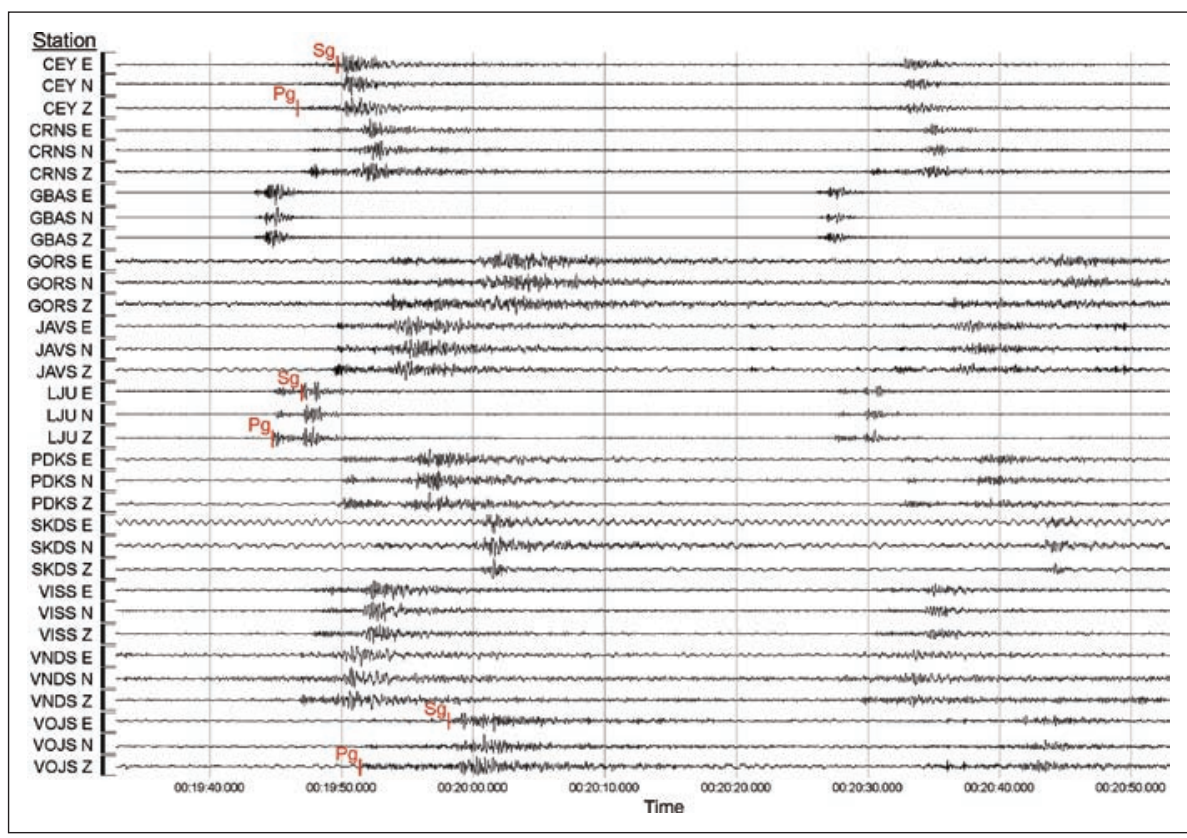

Fig. 7: Seismogram of two consecutive earthquakes ( $M l=0.5$ and 0.2) on September 21, 2010 at 00:19 and 00:20 UTC. Locations of seismological stations are shown in Fig. 1. For each station, identified by 3 or 4 letters code, three components of ground motion (vertical Z, N-S and E-W) are shown (last letter on y axis). Some Pg and Sg phase arrivals are shown as well.
The accuracy of earthquake parameter determination (epicentre coordinates and hypocenter depth) depends mostly on the relative position of stations in relation to the hypocenter, and to the accuracy of the velocity model. Parameters are better determined when records are made in close vicinity and the epicentre is surrounded by seismological station in all directions (good azimuthal coverage or small azimuthal gap). At the beginning of modernisation of the national seismological network in 1998 a numerical simulation was made in order to determine the capacity of the planned network of 25 stations in terms of predicted uncertainties of epicentre and hypocenter determina- 


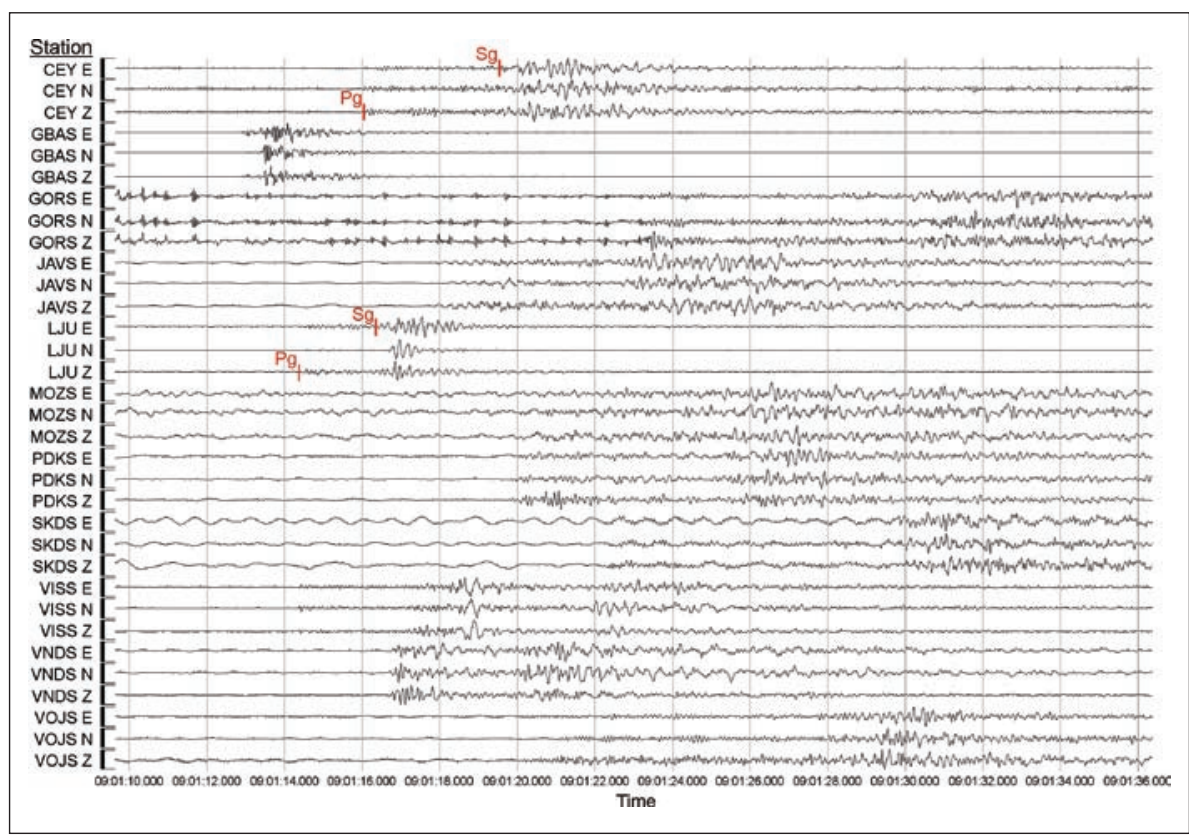

Fig. 8: Seismogram of the earthquake $(M l=0.6)$ on September 26, 2010 at 09:01 UTC.

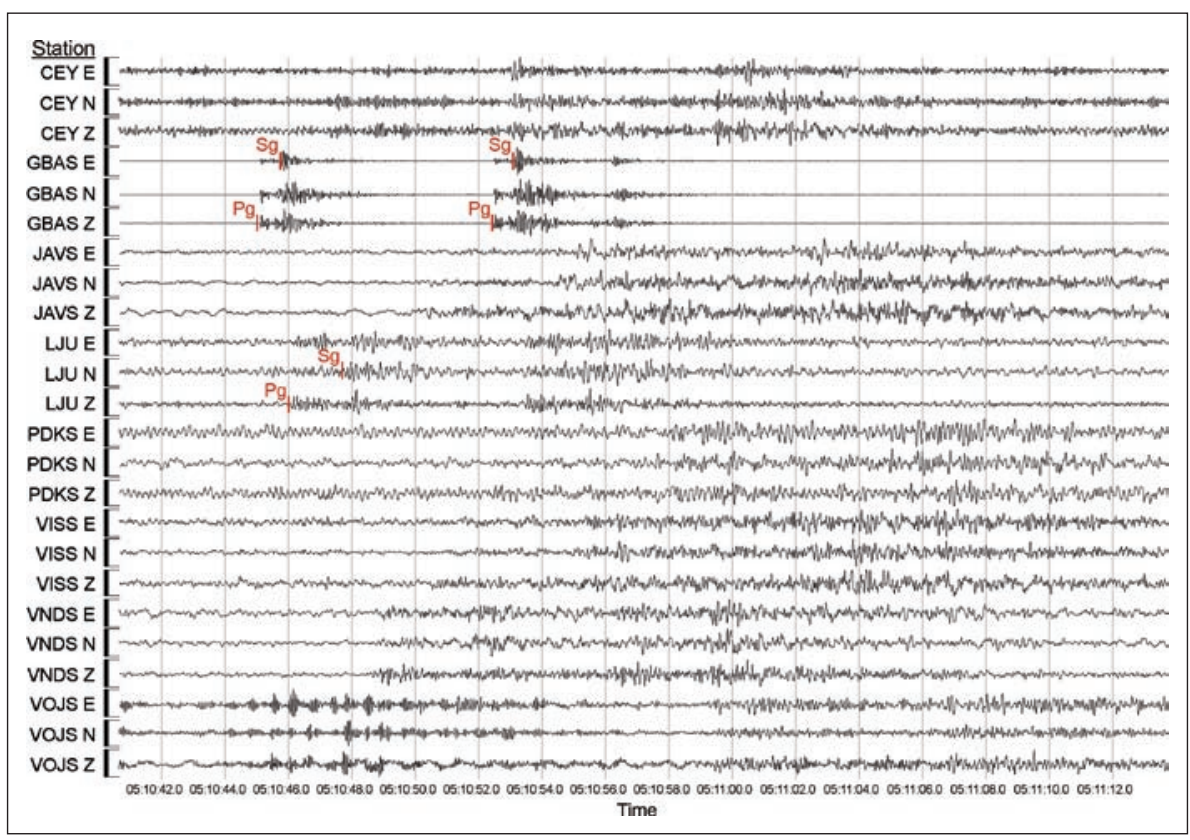

Fig. 9: Seismogram of two consecutive earthquakes (Ml=0.2 and 0.3) on October 4, 2010 at 05:10 UTC.

seismological phase. Earthquakes were located with HYPOCENTER programme (Lienert et al. 1988; Lienert 1994) using average $1 D$ velocity model for Slovenia (Tab. 2), determined from the $3 \mathrm{D}$ velocity model for body waves (Michelini et al. 1998), and model for surface waves (Živčić et al. 2000).

Two strongest earthquakes, $\mathrm{M}_{\mathrm{L}}=0.5$ on September 21 (Fig. 7) and $M_{L}=0.6$ on September 26 (Fig. 8), were recorded on 14 and 13 seismological stations respectively. Although the second event is slightly stronger, seismic phases could be undoubtedly determined on one station less than for the first event. This can be explained by lower ambient noise during the night time (00:19 UTC) when the first event occurred (Fig. 7) than it was during the day time (09:01 UTC) when the second one occurred (Fig. 8). This resulted in a better signal to noise ratio, which is clearly evident, if we compare both seismograms. All other weaker earthquakes $\left(\mathrm{M}_{\mathrm{L}}=0.2-0.3\right)$ were recorded by 6 to 11 seismological stations. For the last event seismic phases could be picked on only 6 stations, because part of the signal was masked by the preceding event, which occurred seven seconds earlier. The azimuthal gap was

tion for earthquakes of different magnitude (Vidrih et al. 2006). According to this study the uncertainty of epicentre determination in the Ljubljansko barje area is around $1 \mathrm{~km}$, but closer to individual seismological stations it is even better.

Analysis of seismograms enclosed determination of longitudinal (Pg phase) in transversal (Sg phase) waves arrivals on each seismological station where signal to noise ratio allows undoubted determination of particular for all events, with exception of the last one, between $74^{\circ}$ and $88^{\circ}$ (Tab. 1). Since also the Root Mean Square (RMS) residual misfit of hypocenter determination does not vary considerably (range 0.3-0.4 s, only for one event it was $0.2 \mathrm{~s}$ ) we can conclude that the accuracy of epicentre determination is comparable for all events. RMS residual misfit is computed from a set of travel times for a given hypocenter and origin time and represents a measure of the accuracy of the solution (Lienert 1994). Also the es- 
Tab. 2: Velocity model used for locating earthquakes.

\begin{tabular}{c|c|c}
\hline Depth $(\mathrm{km})$ & $V \boldsymbol{p}(\mathrm{km} / \mathrm{s})$ & $V \mathbf{s}(\mathrm{km} / \mathrm{s})$ \\
\hline-1 & 5.55 & 3.299 \\
\hline 0 & 5.60 & 3.299 \\
\hline 1 & 5.64 & 3.299 \\
\hline 2 & 5.68 & 3.299 \\
\hline 3 & 5.72 & 3.299 \\
\hline 4 & 5.75 & 3.299 \\
\hline 5 & 5.765 & 3.299 \\
\hline 7 & 5.765 & 3.306 \\
\hline 14 & 5.765 & 3.39 \\
\hline 18 & 5.78 & 3.44 \\
\hline 19 & 5.81 & 3.46 \\
\hline 20 & 5.85 & 3.48 \\
\hline 21 & 5.90 & 3.50 \\
\hline 22 & 5.95 & 3.52 \\
\hline 23 & 6.01 & 3.54 \\
\hline 24 & 6.08 & 3.56 \\
\hline 25 & 6.15 & 3.58 \\
\hline 26 & 6.22 & 3.60 \\
\hline 27 & 6.29 & 3.62 \\
\hline 30 & 6.65 & 3.85 \\
\hline 40 & 8.00 & 4.55 \\
\hline & &
\end{tabular}

$\mathrm{V}_{\mathrm{p}}=5.6 \mathrm{~km} / \mathrm{s}$ and $\mathrm{V}_{\mathrm{s}}=3.299 \mathrm{~km} / \mathrm{s}$. Distance of the seismological station from the epicentre $\mathrm{D}$ is computed using equation

$\mathrm{D}=\left(\mathrm{T}_{\mathrm{S}}-\mathrm{T}_{\mathrm{p}}\right) /\left(1 / \mathrm{V}_{\mathrm{S}}-1 / \mathrm{V}_{\mathrm{p}}\right)$

where

$\mathrm{T}_{\mathrm{S}}$ - arrival time of S-waves,

$\mathrm{T}_{\mathrm{P}}$ - arrival time of P-waves,

$\mathrm{V}_{\mathrm{S}}$-velocity of S-waves,

$\mathrm{V}_{\mathrm{P}}$ - velocity of P-waves.

The $\mathrm{T}_{\mathrm{S}}-\mathrm{T}_{\mathrm{P}}$ difference for considered earthquakes was between 0.55 and $0.76 \mathrm{~s}$. This gives a range of epicentral distances between 4 and $6 \mathrm{~km}$, which is in agreement with actual locations of epicentres derived from phases picked at all seismological stations using HYPOCENTER programme.

Detailed analysis of seismograms of all events (Figs. 7, 8 and 9) and their comparison with earthquake seismograms recorded daily by the Slovenian seismological network has shown that they are very similar. Therefore it is very likely that the recorded events in the Iška vas area are tectonic earthquakes. Although almost no seismograms of collapse earthquakes are published in the
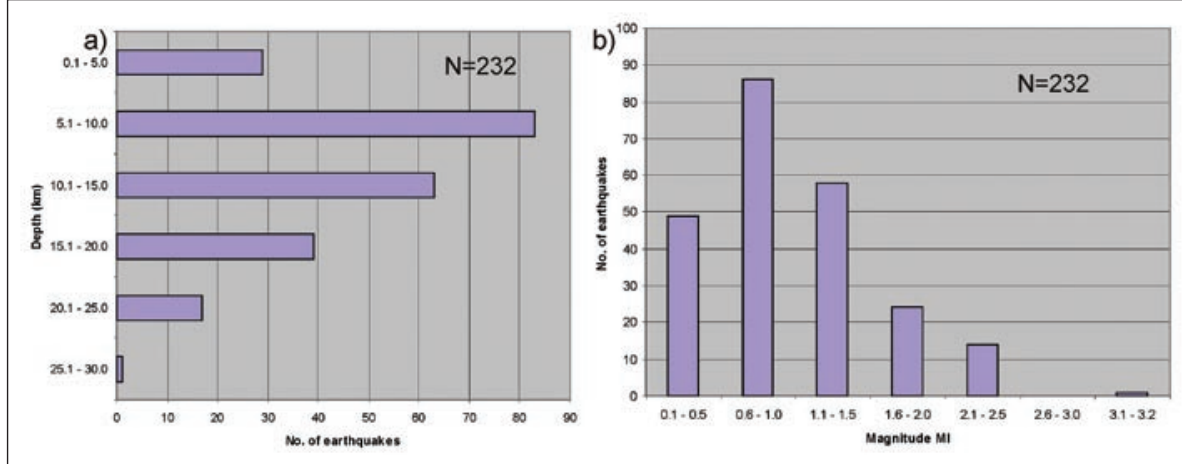

Fig. 10: Seismicity at the southern rim of Ljubljansko barje for the period 1977-2009 from earthquake catalogue (ARSO 2012). a) depth distribution of hypocentres, b) magnitude distribution.

timated hypocentral depth for all events was very stable $(0.0-0.1 \mathrm{~km})$, which means that they were extremely shallow.

The accuracy of earthquake location, especially of the hypocentral depth, strongly depends on the distance to the nearest seismological station. In the case of Iška vas earthquakes, the distance to GBAS station was only $4-6 \mathrm{~km}$ (Fig. 3) and the distance to LJU station $10 \mathrm{~km}$ (Fig. 1). All other seismological stations are located more than $20 \mathrm{~km}$ far from the epicentral area (Fig. 1). Since the earthquakes were very shallow (at the depth from 0.0 to $0.1 \mathrm{~km}$ ) we can expect that the travel path of Pg and Sg phases to GBAS station were limited to the topmost layer of $1 \mathrm{D}$ velocity model (Tab. 2) used for location, which is characterized by literature, we can assume that they are in general different. be so short in duration (so impulsive) as in the case of a tectonic earthquake. Therefore, it will result in a less impulsive signal, less sharp arrivals of $\mathrm{Pg}$ and Sg phases and in longer ground motion. Collapse earthquakes are probably more similar to the artificial quarry blasts regularly recorded also by the Slovenian seismological network. Since millisecond delay devices are normally used in massive quarry blasting, their seismic signal is never so sharp as in a case of tectonic earthquakes (Siskind et al. 1980).

Brontides (a rumbling noise) itself, which were heard during the first two earthquakes as well as for some later events are not an indication, which can be used to distinguish between tectonic and collapse earthquakes. Brontides are low frequency, rumbling, thunder like sounds of short duration of seismic origin most frequently heard in active seismic regions. Brontides are quite frequently observed in Slovenia during earthquakes for events, which are undoubtedly of tectonic origin. They are characteristic especially for earthquakes with shallow hypocenters. The collapse of a cave roof or similar structure can never 
We compared the extremely shallow hypocentral depth of this series of earthquakes with the depth distribution of other events in the area monitored in the period 1997-2009 (Fig. 2). We considered all the events from the catalogue (ARSO 2012), which occurred close to the southern rim of Ljubljansko barje for which similar tectonic regime can be expected. There were 232 such events. The depth distribution of hypocentral depths and magnitude distribution are shown in Fig. 10. The aver- age hypocental depth is $11.1+/-5.6 \mathrm{~km}$, with the highest number of earthquakes in the range 5-10 km, followed by the $10-15 \mathrm{~km}$ range. The average magnitude of the same group of events is $1.0+/-0.55$, with the highest number of earthquakes in the 0.6-1.0 magnitude range. Thus, it is very clear that the September-October 2010 events deviate significantly from the normal seismicity pattern in the area.

\section{DETERMINATION OF EARTHQUAKES MAGNITUDE}

Local magnitude $\left(\mathrm{M}_{\mathrm{L}}\right)$ was determined from the largest amplitude of ground motion velocity determined on the vertical seismogram component $(\mathrm{A} / \mathrm{T}$ in $\mathrm{nm} / \mathrm{s})$ using the equation (Cecić et al. 2010)

$\mathrm{M}_{\mathrm{L}}=\log (\mathrm{A} / \mathrm{T})+1,52 \log \mathrm{D}-3,2$

where $\mathrm{D}$ is the epicentral distance in kilometres.
Variability of magnitudes for the same event as determined at different seismological stations was reasonable and is in agreement with variability observed in routine analysis of seismic events in Slovenia. It can be accounted mainly to the specific local site conditions at each seismological station. Some stations tend to exaggerate the estimated magnitude and some to diminish it. From Fig. 11 it can be seen that Ljubljana (LJU) seismological station gave for almost all events the highest value and that Javornik (JAVS) and Višnje (VISS) seismological stations gave mostly the lowest values. For the two strongest events it was possible to determine magnitudes on eight seismological stations, and for all other events on two to five stations.

Computation of fault plain solutions (focal mechanisms) could provide addi-

Magnitudes were computed from the maximum A/T ratios measured on seismograms from all seismological stations where Pg and Sg seismic phases were picked and where the signal to noise ratio in the part of the seismogram, which follows Sg arrival allowed this. Local magnitudes of all earthquakes as determined from seismograms recorded at different seismological stations are shown on Fig. 11 together with their average, which is shown also in the last column of Table 1. tional contribution to the characterization of observed events, i.e. mode of their origin and the orientation of the fault on which they occurred. Unfortunately, the number of seismological station on which the sense of the first ground motion could be undoubted determined was too small, because the events were rather weak - local magnitude range from 0.2 to 0.6 . Therefore, it was not possible to derive fault plain solution for any of the recorded earthquakes. 


\section{CONCLUSIONS}

Observed seismicity in the Iška vas area in the period from September 21 to October 4, 2010 is unusual, since the hypocentral depth of earthquakes at the southern rim of Ljubljansko barje basin is normally in the range from at least $2 \mathrm{~km}$ and down to $15 \mathrm{~km}$, but these events occurred at or near the surface. Their epicentres are in good agreement with the location of the dried river bed; sinking of river Iška appeared in parallel to the beginning of seismic activity. It is therefore very likely that both phenomena are related. Performed analyses of seismograms have shown that it is not likely that the observed events are collapse earthquakes, but they are probably tectonic events. Although they were relatively weak, it seems that they could be accompanied by small tectonic movements, because they occurred at the position of a well developed NW-SE striking Mišji dol fault at the bot- tom of the valley. These movements are probably related to the changed hydrogeological conditions. Therefore, it is not impossible that rapid changes of underground hydrological regime have influenced the stress-strain conditions in the vicinity of the fault and triggered observed earthquakes, but there are no proofs available to confirm such hypothesis. Tectonic movements are probably connected to the opening of pre-existing fissures in the karstified valley bottom. Flood wave removed up to 1.5 $\mathrm{m}$ of the low permeable clogged river bed and heavy precipitation induced temporary high groundwater levels in karstified bedrocks, clearing karstified fissures within, filled with fine grained sediments. Latter when hydraulic head in bedrock karstic aquifer dropped, conditions for intensive sinking of the water into the underground were formed.

\section{REFERENCES}

ARSO, 2008: Hidrološki letopis Slovenije 2008. Environment Agency of Slovenia, available at www.arso.si.

ARSO, 2010: Iška river hydrograph for September 2010. http://www.arso.gov.si/vode/podatki/amp/Hg_1.html (accessed 1.11.2010)

ARSO, 2011: Iška river discharge data. http://vode.arso. gov.si/hidarhiv/index.php

ARSO, 2012: Earthquake catalogue of Slovenia for $1977-$ 2009. Environment Agency of Slovenia.

Bolt, B. A., 1993: Earthquakes. Freeman and co., 331 pp.

Brenčič, M., 2011: Zakaj je izginila reka Iška. Slovenski vodar, 23-24, 80-83.

Cecić, I., Jesenko, T., Živčić, M. \& M. Čarman, 2010: Potresi v Sloveniji leta 2009. Potresi v letu 2009, Agencija RS za okolje, 49-64.

Fairhurst, C., 1990: Rockbursts and seismicity in mines. Balkema, 439 pp.

Globevnik, L. \& A. Vidmar, 2010: Poplave na Ljubljanskem barju septembra 2010. Mišičev vodarski dan 2010, $24-29$.

Gosar, A. \& A. Lenart, 2010: Mapping the thickness of sediments in the Ljubljana Moor basin (Slovenia) using microtremors. Bull. of Earthquake Eng., 8, 501-518.

Janža, M., Meglič, P., Šram, D., Prestor, J., Skaberne, D. \& D. Rozman, 2011: Improvement of hydrological conceptual and geological model (INCOME Project report). Geological Survey of Slovenia, Ljubljana.
Lienert, B.R., Berg, E. \& L.N. Frazer, 1988: HYPOCENTER - An earthquake location method using centered, scaled, and adaptively least squares. Bull. Seism. Soc. Am., 76, 771-783.

Lienert, B.R., 1994: HYPOCENTER 3.2 - A computer program for locating earthquakes locally, regionally and globally. Hawaii Institute of Geophysics \& Planetology, Honolulu, 70 pp.

Mencej, Z., 1989: Prodni zasipi pod jezerskimi sedimenti Ljubljanskega barja. Geologija, 31-32, 517-553.

Michelini, A., Živčić, M. \& P. Suhadolc, 1998: Simultaneous inversion for velocity structure and hypocenters in Slovenia.- J. of Seismology, 2-3, 257-265.

Ribarič, V., 1984: Potresi, Cankarjeva založba, 271 pp., Ljubljana

Siskind, D.E., Stagg, M.S., Kopp, J.W. \& C.H. Dowding, 1980: Structure response and damage produced by ground vibration from surface mine blasting. US Department of interior, Bureau of mines, Report of investigations 8507, $74 \mathrm{pp}$.

Vidrih, R., Sinčič, P., Tasič, I., Gosar, A., Godec, M. \& M. Živčić, 2006: Seismic network of Slovenia. Environmental Agency of the Republic of Slovenia, 287 pp., Ljubljana.

Živčić, M., Bondár, I. \& G.F. Panza, 2000: Upper crustal velocity structure in Slovenia from Rayleigh wave dispersion. Pure Appl. Geophys., 157, 131-146. 